\title{
VILNIAUS UNIVERSITETO MEDICINOS FAKULTETO STUDENTŲ NEMIGOS SIMPTOMAI
}

\author{
Beatričè Balčiūnaitė ${ }^{1}$, Vaiva Būgaitè ${ }^{1}$, Marius Karnickas ${ }^{2}$ \\ ${ }^{1}$ Vilniaus universiteto Medicinos fakultetas, ${ }^{2}$ Respublikine Vilniaus psichiatrijos ligoninè
}

Raktažodžiai: nemiga, benzodiazepinai, $\mathrm{Z}$ vaistai.

\section{Santrauka}

Biomedicinos mokslų studentai dažnai patiria miego sutrikimus. Tyrimo tikslas - nustatyti nemigos simptomų paplitimą tarp Vilniaus universiteto Medicinos fakulteto studentų, ivertinti jų sunkumą, taikant nemigos sunkumo indeksą ISI (angl. Insomnia Severity Index), išsiaiškinti, kokias priemones biomedicinos studentai renkasi miego sutrikimų gydymui.

Tyrimo medžiaga ir metodai. 2020 m. gruodžio - 2021 $\mathrm{m}$. vasario mènesiais ị internetinę apklausą iš 32 pasirenkamujų atsakymų i klausimus atsakè 416 Vilniaus universiteto Medicinos fakulteto biomedicinos studentų. Duomenys apdoroti Excel programa ir laikyti statistiškai reikšmingais, kai $\mathrm{p}<0,05$.

Rezultatai. Apklausti visų VU MF studijų programų studentai. Iš jų: medicinos $-44,5 \%$, farmacijos $-12,3 \%$, kineziterapijos $-12,3 \%$, odontologijos $-8,9 \%$, visuomenès sveikatos $-8,9 \%$, ergoterapijos $-7,2 \%$, slaugos $-5 \%$, kiti $-1 \%)$. Iš 416 respondentų $352(84,6 \%)$ moterys ir $64(15,4 \%)$ vyrai. Kliniškai reikšmingi nemigos simptomai, ivvertinti ISI, nustatyti 165 studentams iš $416(39,7 \%)$. Vidutinio sunkumo klinikinès nemigos simptomai nustatyti 119 iš 416 (29\%), sunkios - 46 iš 416 studentų (11\%). Tik 50 (12\%) iš 416 biomedicinos studentų žinojo, kad ilgiausia galima ūmios nemigos gydymo benzodiazepinais trukmè yra 1 mènuo. Iš 227 studentų, patyrusių nemigos simptomus, net $65(28,6 \%)$ užmigimui palengvinti vartojo alkoholị. Iš 227 studentų, patyrusių nemigos simptomus, $152(67 \%)$ teigè vartoję žolinius preparatus, $87(38,3 \%)$ - melatonino preparatus, $54(23,8 \%)$ - benzodiazepinus, 28 (12,3\%) - antidepresantus, 20 (8,8\%) -Z vaistus, 8 (3,5\%)-kvetiapiną, o 56 $(24,7 \%)$ teigè nevartoję čia nurodytų vaistinių preparatų. Net 18 iš $54(33,3 \%)$ studentų, nemigos simptomų gydymui vartojusių benzodiazepinus, patyrè mažiausiai vieną šalutinị reiškini, o 4 (7,4\%) atitiko priklausomybès sindromo diagnostikos kriterijus. Net 11 iš 20 (55\%) studentų, nemigos simptomu gydymui vartojusių $Z$ vaistus, patyrè mažiausiai vieną šalutinị reiškinį, o $3(15 \%)$ atitiko priklausomybès sindromo diagnostikos kriterijus. Išvados. Kliniškai reikšmingus nemigos simptomus, ịvertintus ISI, patyre 165 studentai iš $416(39,7 \%)$. Merginy ISI ịverčiai buvo statistiškai reikšmingai aukštesni, nei vaikinų ( $\mathrm{p}=0,0034)$. Ne medicinos programų studentų ISI įverčiai buvo statistiškai reikšmingai aukštesni, nei medicinos studentų ( $p=0,0001)$. Didžiausias nemigos simptomų paplitimas nustatytas tarp kineziterapijos (55\%), mažiausias - tarp medicinos studentų (31\%).

\section{Ivadas}

Šis tyrimas yra antrasis tokio pobūdžio tyrimas, skirtas ịvertinti Lietuvos biomedicinos studentų miego sutrikimus. Vilniaus universiteto Medicinos fakulteto ir Lietuvos sveikatos mokslų universiteto medicinos studentų miego kokybę vertinusiame tyrime 2019-2020 metais buvo nustatyta, kad nemigos simptomai pasireiškè 55,5 proc. studentų. Tyrimo metu studentai patys subjektyviai vertino savo nemigos simptomus, nenaudodami nemigos klausimynų, pvz. Pitsburgo miego kokybės indekso PSQI (angl. Pittsburgh Sleep Quality Index) ar nemigos sunkumo indekso ISI (angl. Insomnia Severity Index) [1]. Nemigos simptomatika buvo įvertinta reliatyviai subjektyviai ir nemigos simptomų nebuvo galima sugrupuoti, pvz., pagal nemigos sunkumą ar kitaip kiekybiškai įvertinti. Tyrimas buvo vykdomas COVID-19 pandemijos pradžios metu, paliekant erdvès hipotezėms, jog miego sutrikimai galèjo pasireikšti dèl naujų gyvenimo aplinkybių ir neatspindi realybès.

Šiuo tyrimu siekta pakartotinai ir tiksliau ištirti studentų miego kokybę, nemigos simptomų paplitimą ir specialiais klausimynais nuodugniau išnagrinèti nemigos simptomų sunkumą. Pasirinkta šiek tiek kitokia tiriamujų grupé-ne tik medicinos studentai, bet visų medicinos fakulteto (MF) specialybių studentai. Tokiu pasirinkimu norèta ne tik bendrai įvertinti MF studentų miego kokybę, bet ir patikrinti itin dažną nuostatą, jog daugiausia miego sutrikimų patiria medicinos specialybės studentai. 
Tyrimo tikslas - nustatyti nemigos simptomų paplitimo dažnį, nemigos sunkumo indeksą (ISI), patikrinti biomedicinos studentų žinias apie didžiausią rekomenduojamą ūminès nemigos gydymo benzodiazepinais trukmę. Ištirti, kokias medikamentines ir nemedikamentines priemones studentai renkasi nemigos simptomams gydyti, benzodiazepinų ir Zvaistų vartojimo dažnį nemigos simptomams gydyti ir jų šalutinị poveikị, įskaitant galimybę sukelti priklausomybę.

\section{Tyrimo medžiaga ir metodai}

Tyrime dalyvavo 416 Vilniaus universiteto medicinos fakulteto biomedicinos studentų. Lyčių pasiskirstymas atspindejo lyčių pasiskirstymą tarp studijuojančiujų - iš 416 respondentų $352(84,6 \%)$ buvo moterys ir $64(15,4 \%)$ vyrai. Didžiausią atsakiusiųjų dalį sudare medicinos studentai 185 (44,5\%). Likusiųų programų studentų pasiskirstymas buvo gan tolygus: 51 studijavo farmaciją (12,3\%), 51 kineziterapiją (12,3\%), 37 odontologiją (8,9\%), 37 visuomenés sveikatą $(8,9 \%), 30$ ergoterapiją $(7,2 \%), 21$ slaugą $(5 \%), 4$ (1\%) nurodè atsakymą „,kita“. I klausimus atsakè 104 pirmakursiai $(25,1 \%), 85$ antrakursiai $(20,5 \%), 85$ trečiakursiai (20,5\%), 60 ketvirtakursių (14,5\%), 50 penktakursių (12\%), 31 šeštakursis $(7,5 \%)$.

I Google Forms programa sukurtą internetinę apklausą biomedicinos mokslų studentai galejo atsakyti nuo $2020 \mathrm{~m}$. gruodžio iki $2021 \mathrm{~m}$. vasario. Anketą sudare 32 pasirinktinių atsakymų testo klausimai, iš kurių 7 atitiko ISI klausimus, o trys pirmieji klausimai buvo skirti surinkti informaciją apie tyrimo dalyvių lytį, studijų programą ir kursą. I penktaji klausimą „Ar studijų metu patyrète miego sutrikimų? (mažiausiai 3 naktis per savaitę turẻjote sunkumų išsimiegoti ir tai truko mažiausiai vieną mėnesį)“ atsakius neigiamai, apklausa pasibaigdavo. Šis klausimas buvo suformuluotas remiantis trečiuoju Tarptautinès miego sutrikimų klasifikacijos leidimu (ICSD-3): nemiga yra miego sutrikimas, pasireiškiantis bent 3 naktis per savaitę ir trunkantis bent 1 ménesi [2]. Surinkti duomenys buvo apdoroti Excel programa, o statistinis reikšmingumas ịvertintas taikant T-test statistini testą. Vertès laikytos statistiškai reikšmingomis, kai $\mathrm{p}<0,05$.

\section{Tyrimo rezultatai}

Tyrimo metu nustatyta, kad iš 416 biomedicinos studentu tik $50(12 \%)$ žinojo, kad didžiausia rekomenduojama ūmios nemigos gydymo benzodiazepinais trukmé yra 1 mènuo. 255 $(61,3 \%)$ tiriamujų atsakymo nežinojo, $68(16,3 \%)$ pasirinko atsakymą „dvi savaitès“, 25 (6\%) - „savaite“, 14 (3,4\%) „du mènesiai“, 4 (1\%) - ,pusè metu“".

Iš 416 biomedicinos studentų $227(54,6 \%)$ studijų metais patyrè nemigos simptomų - mažiausiai 3 kartus per savaitę turejjo sunkumų išsimiegoti ir tai truko mažiausiai vieną mėnesį. 195 (46,9\%) tiriamiesiems nemigos simptomai pasireiškè šiais mokslo metais.

Iš 227 studentų, patyrusių nemigos simptomus:

- 97 (42,7\%) nemigos simptomai truko vieną mènesį, $79(34,8 \%)$ - nuo vieno iki trijų mėnesių, o $51(22,5 \%)$ ilgiau kaip tris mėnesius. Ilgiau kaip tris mènesius trunkanti nemiga laikoma lètine [2];

- $76(33,5 \%)$ šie simptomai pasireiške tris naktis per savaitę, $53(23,3 \%)$ - keturias naktis per savaitę, $50(22 \%)$ - penkias naktis per savaitę, 17 (7,5\%) - šešias naktis per savaitę, $31(13,7 \%)$ - septynias naktis per savaitę;

- $40(17,6 \%)$ per nakti miegodavo 6 ir daugiau valandu, $170(74,9 \%)$ - nuo trijų iki penkių valandų, o $17(7,5 \%)-$ iki dviejų valandų;

- $183(80,6 \%)$ teigè neturejję gretutinių ligų, $30(13,2 \%)$ nustatytas nerimo sutrikimas, $20(8,8 \%)$ - depresija, 18 $(7,9 \%)$ - panikos sutrikimas, $4(1,8 \%)$ - adaptacijos sutrikimas, $1(0,4 \%)$ - miego apnejja, $3(1,3 \%)$ - kita somatinè liga, trukdžiusi išsimiegoti;

- 135 (59,5\%) simptomai buvo susiję su svarbiais jų gyvenimo ịvykiais. Iš jų $121(89,6 \%)$ nurodè, kad miegą trikdè akademiniai atsiskaitymai, 77(57\%) - konfliktai, 49 (36,3\%) - COVID-19 pandemija, 25(18,5\%) - netektis, $24(17,8 \%)$ - skyrybos, $18(13,3 \%)$ - liga, 43(31,3\%) nurodè atsakymą ,kita“.

- $129(56,8 \%)$ mėgino riboti kofeiną antroje dienos pusèje, 85 (37,4\%) prieš miegą ribojo naudojimąsi elektroninèmis priemonemis, skleidžiančiomis mèlynosios šviesos bangas, $55(24,2 \%)$ išbandè meditaciją, 18 (7,9\%) - psichoterapiją (pvz., kognityvinę elgesio terapiją), 12 (5,3\%) - autogeninę treniruotę, $9(4 \%)$ - miego hipnozę, $2(0,9 \%)$ akupunktūrą, o 68 (30\%) neišbandè nè vienos iš čia išvardytų nemedikamentinių miego gerinimo priemonių.

- $65(28,6 \%)$ teigè vartoję alkoholi, siekdami užmigti;

- 152 (67\%) teigè vartoję žolinius, 87 (38,3\%) - melatonino preparatus, $54(23,8 \%)$ - benzodiazepinus, 28 (12,3\%) - antidepresantus, $20(8,8 \%)-Z$ vaistus, $8(3,5 \%)$ - kvetiapiną, o $56(24,7 \%)$ teigè nevartoję nė vienų iš čia nurodytų vaistinių preparatų.

Benzodiazepinų vartojimas. Iš 54 studentų, nemigos simptomams gydyti vartojusių benzodiazepinus:

- 34 (63\%) vartojo alprazolamą, $26(48,1 \%)$ - bromazepamą, $11(20,4 \%)$ - diazepamą, 9 (16,7\%) - lorazepamą, $5(9,3 \%)$ - klonazepamą, $4(7,4 \%)$ - triazolamą, $6(11,1 \%)$ rinkosi atsakymą ,kita“;

- 28 (51,9\%) benzodiazepinus vartojo savaitę, 5 (9,3\%) - dvi savaites, $9(16,7 \%)$ - mènesį, $4(7,4 \%)$ - du mènesius, $4(7,4 \%)$ - pusę metų, $4(7,4 \%)$ - metus;

- 28 (51,9\%) patyrè mieguistumą, apdujimą dienos metu, $21(38,9 \%)$ - silpnumą, greitą nuovargí, $17(31,5 \%)$ - svai- 
guli, 17 (31,5\%) - užmaršumą, sunkumus koncentruotis, $10(18,5 \%)$ po tam tikro vaistų vartojimo miego sutrikimo simptomai grižo, $9(16,7 \%)$ turejo vis didinti dozę, nes vaistai èmè nebeveikti, 7 (13\%) - sumažèjo libido, 14 (26\%) nepatyre čia išvardyto šalutinio poveikio;

- $10(18,5 \%)$ pajuto stiprų norą vartoti šiuos vaistus, $8(14,8 \%)$ èmè vartoti vis daugiau, kad pasiektų toki pati efektą, $6(11,1 \%)$ tęsė vartojimą nepaisydami žalingų pasekmių, 4 (7,4\%) patyrè sunkumų kontroliuoti jų vartojimą, 4 $(7,4 \%)$ jaute, kad vartoti šiuos vaistus yra svarbiau už kitas veiklas ir įsipareigojimus, $2(3,7 \%)$ patyrè fizinę abstinenciją, o $36(66,7 \%)$ tokio nepageidaujamo poveikio nepatyre;

- $4(7,4 \%)$ surinko tris arba daugiau iš šešiu priklausomybès sindromo diagnostikos kriterijų. Klinikinèje praktikoje asmenims, kuriems nustatomi trys iš šešių diagnostikos kriterijų, diagnozuojamas priklausomybès sindromas [3]. Šie keturi galimai priklausomi asmenys vartojo: 1) alprazolamą ir bromazepamą (pusę metų); 2) diazepamą ir bromazepamą (mènesį); 3) alprazolamą, diazepamą, bromazepamą ir triazolamą (mènesị); 4) alprazolamą ir lorazepamą (du mènesius).

$Z$ vaistų vartojimas. Iš 20 studentų, nemigos simptomams gydyti vartojusių $Z$ vaistus:

- 15 (75\%) vartojo zolpidemą, 6 (30\%) vartojo zopikloną, nè vienas nevartojo zaleplono;

- 9 (45\%) vartojo juos vieną savaitę, $2(10 \%)$ - dvi savaites, 4 (20\%) - mènesí, 2 (10\%) - du mènesius, 2 (10\%) - pusę metų, $1(5 \%)$ - metus;

- 5 (25\%) patyré mieguistumą, apdujimą dienos metu, 4 $(20 \%)$ - svaiguli, 4 (20\%) - turèjo vis didinti dozę, nes vaistai èmè nebeveikti, 3 (15\%) silpnumą, greitą nuovargi, 3 (15\%) po tam tikro vaistų vartojimo miego sutrikimo simptomai vèl grižo, $3(15 \%)$ - patyre užmaršumą, sunkumus koncentruotis, $1(5 \%)$ - libido sumažejimą, 9 (45\%) nepatyrè nè vieno iš šių simptomų;

- $5(25 \%)$ tęsé vartojimą nepaisydami žalingų pasekmių, 4 (20\%) èmé vartoti vis daugiau, kad pasiektų tokị pati efektą, 3 (15\%) jautè stiprų norą vartoti šiuos vaistus, $3(15 \%)$ patyrè fizinę abstinenciją, $3(15 \%)$ turejo sunkumų kontroliuoti šių vaistų vartojimą, $1(5 \%)$ jaute, kad vartoti šiuos vaistus yra svarbiau už kitas veiklas ir ịsipareigojimus, 13 (65\%) nepatyrẻ né vieno šių simptomų;

- 3 (15\%) surinko tris arba daugiau priklausomybès sindromo diagnostikos kriterijų. Klinikinejje praktikoje žmonés, surinkę tiek diagnostikos kriterijų, laikomi priklausomais [3]. Iš šių trijų galimai priklausomų asmenų, du apklaustieji mènesį laiko vartojo vien tik zolpidemą, o vienas pusę metų vartojo ir zolpidemą, ir zopikloną.

Nemigos įvertinimas. Atrinkus 227 studentus, patyrusius nemigos simptomus, jiems buvo pateiktas nemigos sunkumo indekso (ISI) klausimynas, išverstas ị lietuvių kalbą. Klausi- myną sudarè septyni klausimai su penkiais pasirenkamaisiais ịvertinimais, kurių skaitinè vertè svyruoja nuo 0 iki 4 . Respondentai, iš viso surinkę nuo 0 iki 7 balų, nepatiria kliniškai reikšmingos nemigos, nuo 8 iki 14 patiria subklinikinès eigos nemigą, nuo 15 iki 21 - vidutinio sunkumo klinikinę nemigą, nuo 22 iki 28 - sunkią klinikinę nemigą.

Iš 227 studentų, patyrusių nemigos simptomus:

- ị klausimą apie sunkumus užmiegant $9(4 \%)$ atsakè, kad užmigti buvo lengva, 11 (4,8\%) patyrè nežymių sunkumų, 65 (28,6\%) užmigti buvo nelengva, $74(32,6 \%)$ užmigti buvo sunku, 68 (30\%) užmigti buvo labai sunku;

- i klausimą, kaip sunku buvo išmiegoti nepabundant, $25(11 \%)$ atsakè, kad išmiegoti nepabudus buvo lengva, $50(22 \%)$ patyrè nežymių sunkumų, $50(22 \%)$ išmiegoti nepabudus buvo nelengva, $42(18,5 \%)$ sunku, $60(26,4 \%)$ - labai sunku;

- i klausimą, kaip dažnai pabusdavo per anksti, 32 $(14,1 \%)$ atsakè, kad nepabusdavo per anksti, $43(18,9 \%)$ retai pabusdavo per anksti, $62(27,3 \%)$ kartais, 62 (27,3\%) - dažnai, 28 (12,3\%) - labai dažnai pabusdavo per anksti;

- ị klausimą apie pasitenkinimą miego kokybe nè vienas studentas neatsakè, kad yra labai patenkintas miego kokybe, $4(1,8 \%)$ atsakè, kad jaučiasi patenkinti, $41(18,1 \%)$ - iš dalies patenkinti, 105 (46,3\%) - nepatenkinti, 77 (33,9\%) labai nepatenkinti miego kokybe;

- i klausimą, kaip dažnai aplinkiniai pastebejjo miego sutrikimus, $42(18,5 \%)$ atsakè, kad aplinkiniai nieko nepastebejjo, $55(24,2 \%)$ - retai pastebėdavo, kad nemiga blogina miego kokybę, $66(29,1 \%)$ aplinkiniai pastebėdavo kartais, $35(15,4 \%)$ pastebèdavo dažnai, $29(12,8 \%)$ - pastebėdavo labai dažnai;

- ị klausimą apie nemigos keliamą nerimą $14(6,2 \%)$ respondentų atsakè, kad nemiga nekèlè nerimo, $37(16,3 \%)$ kẻlè nedaug nerimo, 85 (37,4\%) - šiek tiek nerimo, 55 (24,2\%) - daug nerimo, $36(15,9 \%)$ - labai daug nerimo;

- i klausimą, kaip stipriai miego sutrikimai sutrikdè kitas veiklas, $6(2,6 \%)$ atsakè, kad nemiga jiems netrukdè, 14 $(6,2 \%)$ - nežymiai trukdè, $42(18,5 \%)$ - šiek tiek trukdè, 92 $(40,5 \%)$ - ganètinai trukdè, $73(32,2 \%)$ - labai trukdè.

Keturi studentai nemigos simptomus patyrè dèl somatinių ligų (vienas iš jų - dèl miego apnèjos). Kadangi miegą sukèlusios priežastys jų atveju buvo somatinès, jie neatitinka neorganinès nemigos apibrěžimo ir jų rezultatai toliau nenagrinejjami.

Pacientams, kuriems diagnozuota depresija, adaptacijos ar nerimo sutrikimai, nemiga laikoma vienu iš šiu sutrikimų simptomų, o ne atskira liga.

Gautas ISI vidurkis tarp studentų yra 17,26, o tai atitinka vidutinio klinikinio sunkumo nemigą. ISI mediana 17 , standartinis nuokrypis 4,59 . Matomas nesimetrinis ISI 
rezultatų pasiskirstymas histogramoje (1 pav.), ISI įvertis svyruoja nuo 6 (nèra kliniškai reikšmingos nemigos) iki 28 (sunki klinikinè nemiga, didžiausias rezultatas ISI skalèje).

Respondentu atsakymų įvertinimas taikant nemigos sunkumo indeksą (ISI) parode, kad nemigos simptomai labiausiai paplitę tarp kineziterapijos (55\% nuo specialybės kurso), ergoterapijos (53\% nuo specialybės kurso) bei visuomenès sveikatos studentų (54\% nuo specialybès kurso) (1 lentelè). Tarp šių trijų specialybių pastebėtas didžiausias kliniškai sunkios nemigos paplitimas pagal ISI: kineziterapijos 16\% (8 iš 51 studento, patyrusio nemigos simptomus), visuomenès sveikatos $16 \%$ (6 iš 31 studento, patyrusio nemigos simpto- mus) ir slaugos studentų net $24 \%$ (5 iš 21 studento, patyrusio nemigos simptomus) (2 pav.). Priešingai išankstiniams ịsitikinimams, tarp medicinos studentų nustatytas vienas mažiausių kliniškai sunkios nemigos simptomų paplitimo - 8\% (15 iš 185 studentų, patyrusių nemigos simptomus). Skiltyje „Kita“ yra tik 4 studentų atsakymai, kurių dèl mažos imties statistiškai interpretuoti neverta.

Atlikus skaičiavimus ir pritaikius T-test, nustatyta, kad medicinos ir ne medicinos specialybių ISI ịvertis skiriasi statistiškai reikšmingai $(p=0,0001)$ - ne medicinos studentu miego kokybè buvo prastesnè.

Lyginant nemigos paplitimą tarp kursų, didžiausias pa-

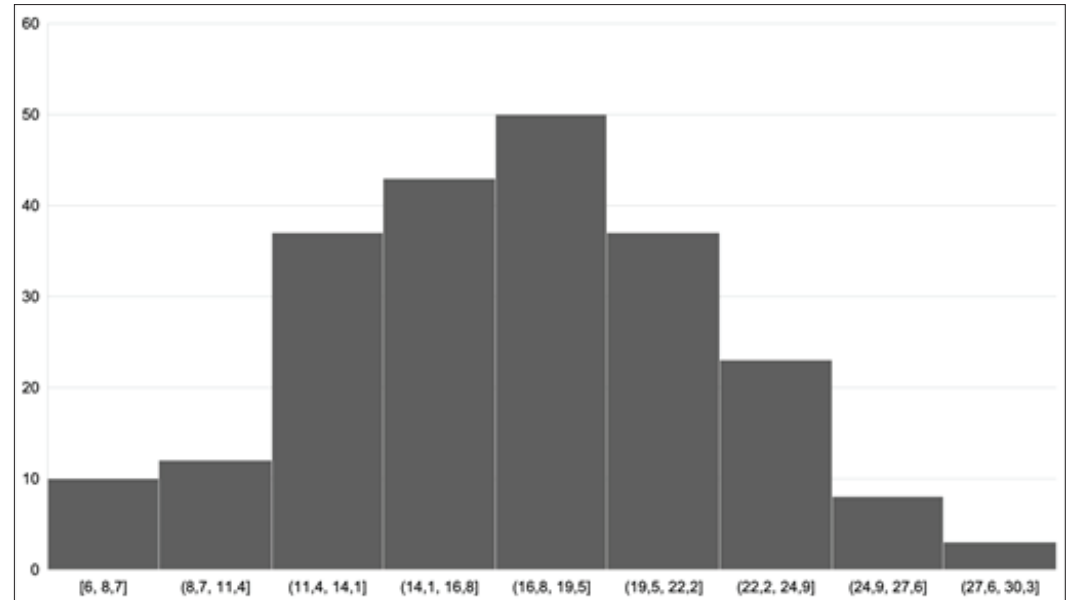

1 pav. ISI pasiskirstymo histograma
1 lentelè. Nemigos simptomų paplitimas tarp skirtingų specialybių studentų.

\begin{tabular}{|l|c|c|c|c|}
\hline \multirow{2}{*}{$\begin{array}{l}\text { Studento } \\
\text { specialybė }\end{array}$} & \multicolumn{3}{|c|}{ Nemigos simptomai } \\
\cline { 2 - 5 } Mepatyre & \multicolumn{2}{|c|}{ patyré } \\
\hline Medicina & 128 & $69 \%$ & 57 & $31 \%$ \\
\hline Odontologija & 27 & $73 \%$ & 10 & $27 \%$ \\
\hline Ergoterapija & 14 & $47 \%$ & 16 & $53 \%$ \\
\hline Kineziterapija & 23 & $45 \%$ & 28 & $55 \%$ \\
\hline $\begin{array}{l}\text { Visuomenės } \\
\text { Sveikata }\end{array}$ & 17 & $46 \%$ & 20 & $54 \%$ \\
\hline Farmacija & 30 & $59 \%$ & 21 & $41 \%$ \\
\hline Slauga & 10 & $48 \%$ & 11 & $52 \%$ \\
\hline Kita & 2 & $50 \%$ & 2 & $50 \%$ \\
\hline
\end{tabular}

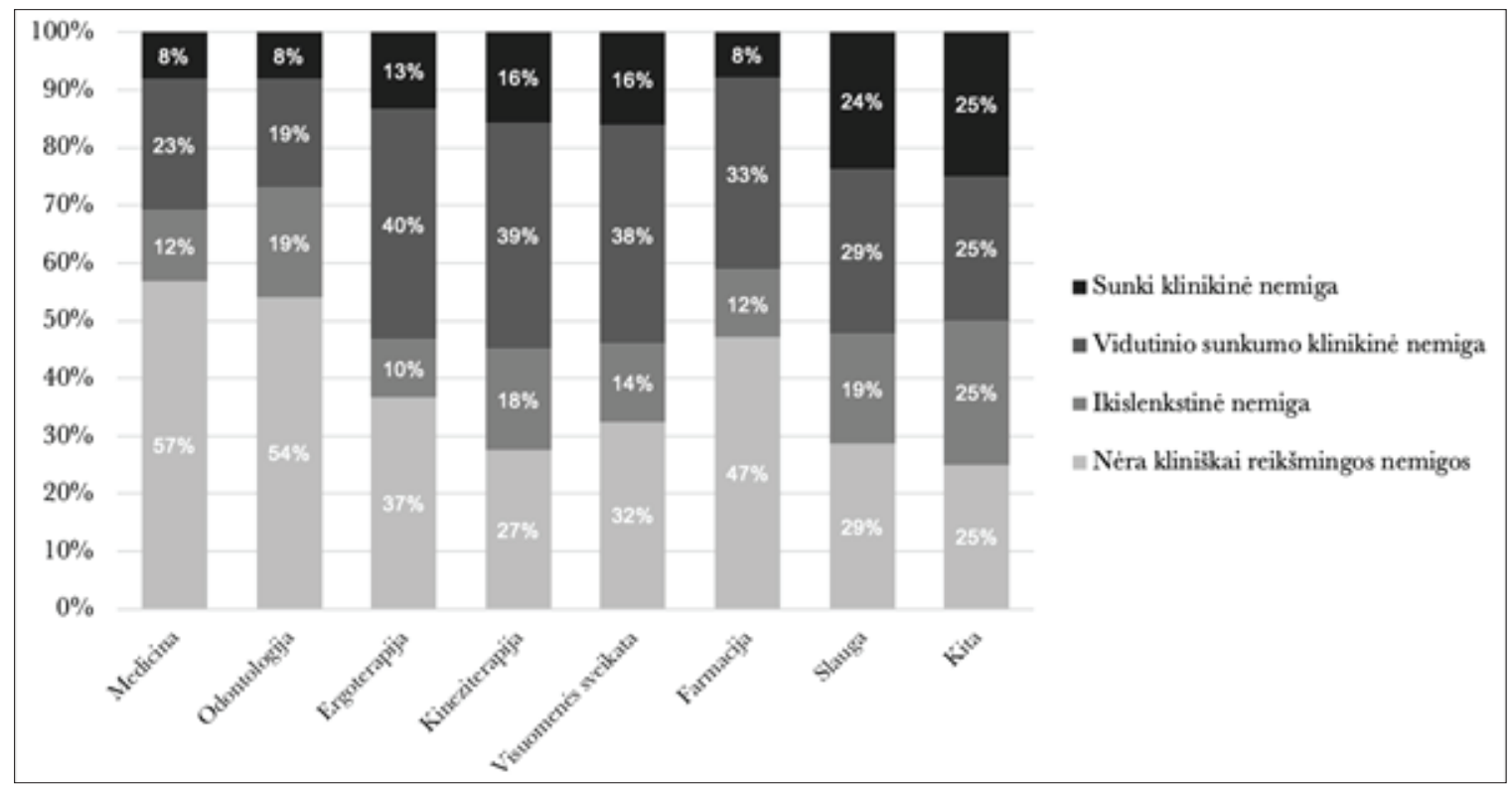

2 pav. Nemigos simptomų (pagal ISI) dažnis tarp skirtingų specialybių studentų 
plitimas pastebètas tarp I kurso studentu (3 pav.). Iš viso 52 iš $104(50 \%)$ pirmakursių patyrè kliniškai reikšmingų nemigos simptomų, 40 iš 104 (38\%) patyrè vidutinio sunkumo klinikinès nemigos simptomų, o 12 iš 104 (12\%) - sunkios klinikinès nemigos simptomų. Nors nemigos simptomai buvo labiausiai paplitę tarp pirmakursių, didžiausia dalis studentų, patyrusių sunkios klinikinès nemigos simptomus, nustatyta tarp šeštakursiu - 6 iš 31 (19\%).

Atlikus skaičiavimus ir pritaikius T-test, nustatyta, kad tarp vyrų ir moterų ISI ịvertis skiriasi statistiškai reikšmingai $(p=0,0034)$ - merginų miego kokybė buvo statistiškai reikšmingai prastesnè.

Iš viso kliniškai reikšmingus nemigos simptomus pagal ISI patyre 165 studentai iš $416(39,7 \%)$. Vidutinio sunkumo klinikinès nemigos simptomus patyre 119 iš 416 studentu (29\%). Sunkios klinikinès nemigos simptomus iš viso patyre 46 iš 416 studentų (11\%).

\section{Diskusija}

Norint patvirtinti nemigos diagnozę, svarbu ne tik kad paciento skundai atitiktų visus reikalingus kriterijus, bet ir atmesti kitas gretutines diagnozes, kurių vienas iš simptomu galètų būti nemiga, pvz., miego apnèja, depresija, nerimo sutrikimai. Nemiga yra nuodugnaus ir visapusio paciento ištyrimo reikalaujanti diagnozè, ją gali diagnozuoti tik gydytojai psichiatrai, neurologai ir šeimos gydytojai. Diagnostika remiasi trečiuoju Tarptautinès miego sutrikimų klasifikacijos leidimu (ICSD-3) [4], pagal kurią turi atitikti šiuos kriterijus: pasireikšti bent 3 naktis per savaitę ir trukti mažiausiai mėnesị; miego sutrikimai neturi būti sukelti išorinių ar somatinių priežasčių. Nemigos negalima diagnozuoti ir tuomet, jei ji yra kitos psichiatrinès ligos (pvz., depresijos ar nerimo sutrikimų) simptomas.

Vienas iš tarptautinių metodų, skirtų nemigos sunkumo laipsniui ivertinti, yra nemigos sunkumo indeksas ( $x$ ISI) septynių klausimų pasirenkamųjų atsakymų klausimynas. Jo pagalba galima greitai ir tiksliai ịvertinti nemigos simptomu sunkumą. Kiekvienas iš septynių klausimų gali būti įvertintas nuo 0 iki 4 balų, o pagal bendrą taškų sumą vertinamas rezultatas: 0-7 nèra kliniškai reikšmingos nemigos, 8-14 subklinikinè nemiga, 15-21 klinikinè nemiga (vidutinio sunkumo), 22-28 klinikinè nemiga (sunki).

2019-2020 metu tyrime nustatyta, kad bendras subjektyviai patiriamų miego sutrikimų dažnis tarp VU MF ir LSMU medicinos studentų yra 55,5 procentai. Šiame tyrime nustatyta, kad iš viso kliniškai reikšmingus nemigos simptomus, vertintus ISI metodu, patyrė 39,7\% studentų (165 iš 416 apklaustujų). Dėl papildomo klausimyno naudojimo galime tikètis, jog šio tyrimo rezultatas yra tikslesnis. Gali būti, kad 2019-2020 metų tyrime buvo įvertinti ir ikiklinikinius nemigos simptomus turèję studentai, kurių skundai prisidèjo prie didesnio bendro nemigos simptomų paplitimo skaičiaus. Lyginant su kitų šalių tyrimais, nemigos simptomų paplitimas VU MF yra gana didelis. Panašaus pobūdžio tyrimas, nagrinejjantis biomedicinos studentu miego kokybę, vertinant pagal ISI, buvo atliktas Libane. Apklausus 462 studentus, 10,6\% nustatyta kliniškai reikšminga nemiga [5]. Palyginimui, šiame tyrime kliniškai reikšmingus nemigos simptomus

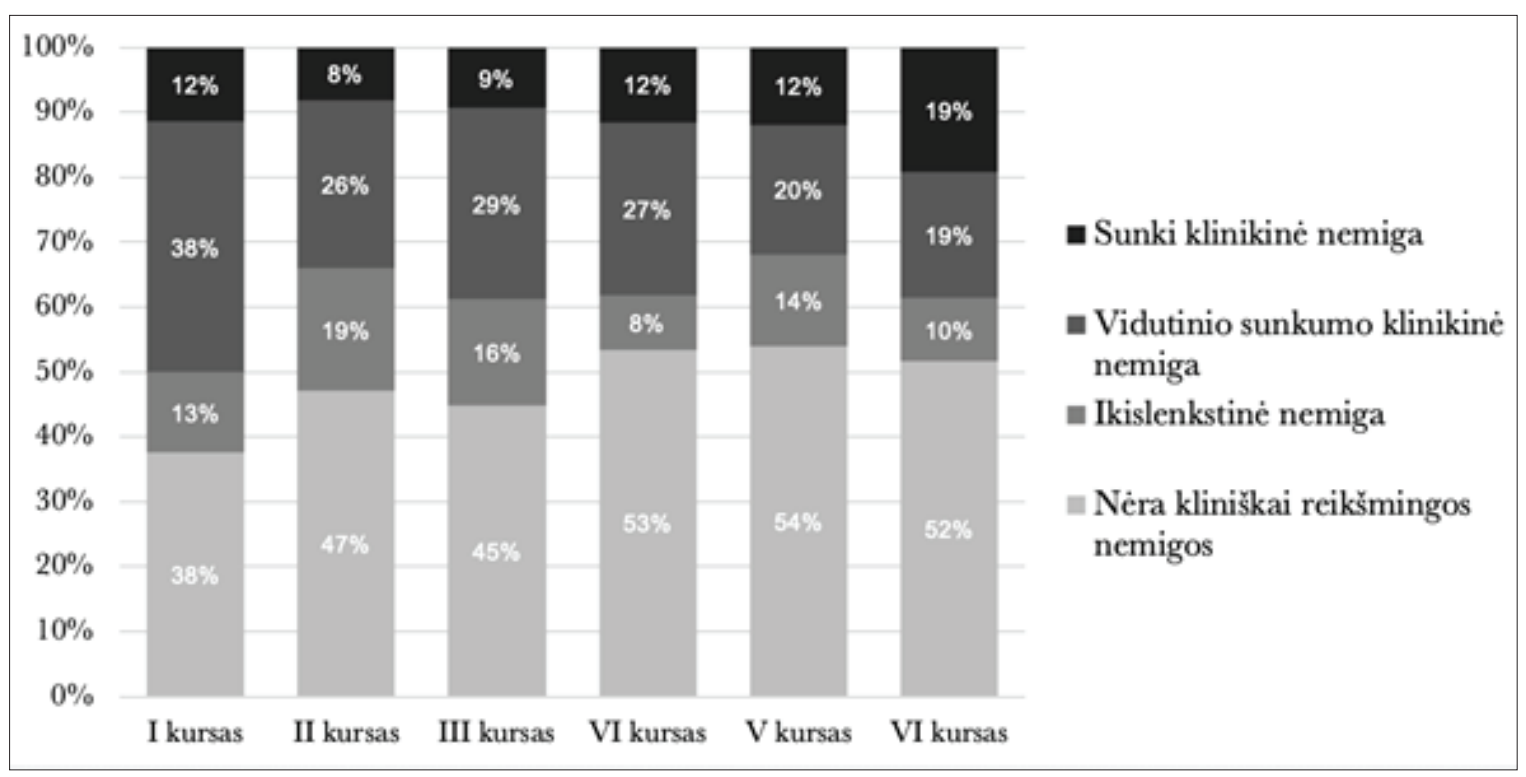

3 pav. Nemigos simptomų paplitimas (pagal ISI) tarp kursų 
(pagal ISI) patyre 165 studentai iš $416(39,7 \%)$ - beveik keturis kartus daugiau. Abiems tyrimams būdinga tai, kad jaunesnių kursų studentai miegojo prasčiau. Italijoje ištyrus slaugos ir medicinos specialybès studentus, nustatyta, kad atitinkamai $44 \%$ ir $63 \%$ studentų išsakè bent vieną miego sutrikimo simptomą. Šio tyrimo metu nustatyta, kad dienos metu pasireiškiantys nemigos sukelti simptomai (pvz., nuovargis) yra statistiškai reikšmingai susiję su nelaimingais atsitikimais darbo vietoje [6]. Saudo Arabijos medicinos mokykloje 2011-2012 m. atlikto tyrimo metu nemigos simptomai pasireiškė $33 \%$ medicinos studentų [7]. Net penkiuose Jordanijos medicinos universitetuose apklausus studentus paaiškèjo, kad $26 \%$ jų studijuodami patyrè kliniškai reikšmingą nemigą [8].

Panašaus tyrimo Teksaso universitete metu apklausus 1074 studentus, nemigos paplitimas buvo nustatytas 9,5 proc. tiriamujų [9]. Apklausus 989 Virdžinijos sandraugos universiteto studentus, nemigos paplitimas atitiko 22,1 procentą [10] .

Vertinant konkrečiai ši VU MF tyrimą, svarbus ne tik galutinis kliniškai reikšmingos nemigos simptomų paplitimas, bet ir tai, kurios studentu grupès išsiskyrè itin prasta miego kokybe. Priešingai, nei būtų galima tikètis pagal studijų krūvị, šiuo tyrimu nustatyta, kad ne mediciną studijuojantys biomedicinos mokslų studentai patiria dar daugiau miego sutrikimų. Atlikus skaičiavimus ir pritaikius T-test, nustatyta, kad medicinos ir ne medicinos specialybių ISI ịvertis skiriasi statistiskai reikšmingai $(\mathrm{p}=0,0001)$ - ne medicinos studentu miego kokybė buvo žymiai prastesnè.

Atlikus skaičiavimus ir pritaikius T-test nustatyta, kad vyrų ir moterų ISI ịvertis skiriasi statistiškai reikšmingai $(p=0,0034)$ : merginų miego kokybė buvo statistiškai reikšmingai prastesnè. 2019-2020 metais atlikto tyrimo metu nebuvo nustatyta statistiškai reikšmingo skirtumo tarp abiejų lyčių patiriamų miego sutrikimų.

Šiuo tyrimu dar siekta ištirti biomedicinos studentu žinias apie benzodiazepinus ir jų vartojimą bei šalutinius požymius. Ši tema pasirinkta todèl, kad benzodiazepinų suvartojimas Lietuvoje yra kur kas didesnis, nei kaimyninèse šalyse - Lietuvoje 2017 m. suvartota 2-3 kartus daugiau, negu kitose Šiaurès regiono šalyse (Suomija, Švedija, Norvegija). Be to, $2017 \mathrm{~m}$. benzodiazepinus Lietuvoje kasdien vartojo apie 4 proc. gyventojų. Šiaurès šalyse du - tris kartus daugiau buvo suvartojama antidepresantų. Kadangi benzodiazepinais dažnai „užglaistomos“ tikrosios problemos, tokios kaip depresija, siektina imti pavyzdį iš Šiaurès šalių ir benzodiazepinus skirti atsargiau [11]. Tai svarbu žinoti ir biomedicinos studentams, būsimiems sveikatos specialistams. Deja, tik 12 proc. atsakiusiujų žinojo, kad ilgiausia ūmios nemigos gydymo benzodiazepinais trukmė yra vienas mėnuo.

\section{Išvados}

1. Kliniškai reikšmingus nemigos simptomus (pagal ISI) patyrè du penktadaliai $(39,7 \%)$ apklausoje dalyvavusių studentur.

2. Kas dešimtas atsakęs ị klausimus patyrè sunkios klinikinès nemigos simptomus (pagal ISI).

3. Tik kas aštuntas respondentas žinojo, kad ilgiausia rekomenduojama ūmios nemigos gydymo benzodiazepinais trukmė yra 1 mènuo.

4. Daugiau kaip kas ketvirtas miego sutrikimus patyręs studentas užmigimui palengvinti vartojo alkoholį.

5. Du trečdaliai patyrusiujų miego sutrikimus vartojo žolinius preparatus, daugiau kaip kas trečias - melatonino preparatus, kone kas ketvirtas - benzodiazepinus, kas aštuntas - antidepresantus, kas vienuoliktas - $Z$ vaistus, daugiau kaip kas trisdešimtas - kvetiapiną.

6. Trečdalis benzodiazepinais nemigą besigydžiusių respondentų patyrè mažiausiai vieną šalutini poveikį, o 4 iš 54 $(7,4 \%)$ šios grupès tiriamujų galima ịtarti priklausomybès sindromą.

7. Daugiau kaip kas antras nemigą $\mathrm{Z}$ vaistais besigydęs studentas patyrè mažiausiai vieną šalutinị reiškinị, o 3 iš 20 (15\%) šios grupès respondentų galima ịtarti priklausomybès sindromą.

8. Didžiausias nemigos paplitimas nustatytas kineziterapijos studentų grupëje.

9. Didžiausias nemigos paplitimas nustatytas tarp pirmakursių, o didžiausias kliniškai sunkios nemigos paplitimas - tarp šeštakursių.

\section{Rekomendacijos}

1. Skatinti biomedicinos mokslų studentus formuoti sveikus miego higienos igūdžius. Tam tikslui galima ị programą įtraukti kursą šia tema, pamėginti tolygiau paskirstyti mokslų krūvị ir kiekvieną dieną paskaitas ar seminarus pradèti tuo pačiu metu.

2. Informuoti studentus, kad ilgiausia ūmios nemigos gydymo trukmè benzodiazepinais yra vienas mènuo dèl rizikos priklausomybei šiems vaistams išsivystyti.

3. Skatinti studentus nemigai gydyti rinktis kognityvinę elgesio terapiją dèl metaanalizèmis patikimai ịrodyto jos veiksmingumo.

4. Nemiga yra vienas iš depresijos, nerimo sutrikimams būdingų simptomų, todèl biomedicinos studentams reikalinga kuo prieinamesnè psichologinè parama.

\section{Literatūra}

1. Balčiūnaitė B., Būgaitè V., Karnickas M. Nemigos simptomų paplitimas tarp medicinos studentų ir benzodiazepinų bei $Z$ vaistų vartojimas jiems gydyti. Neurologijos seminarai, 2020; 24(86). 
2. Sakalauskaitè-Juodeikienė E, Masaitienė R. Naujas nemigos apibrěžimas, etiopatogenezé, diagnostikos ir gydymo algoritmas. Neurologijos seminarai, 2019;22(77):164-73.

https://doi.org/10.29014/ns.2018.20

3. TLK-10-AM/ACHI/ACS elektroninis vadovas. http://ebook.vlk. 1t/e.vadovas/index.jsp

4. Riemann D, Baum E, Cohrs S, Crönlein T, Hajak G, Hertenstein E, et al. S3-Leitlinie Nicht erholsamer Schlaf/Schlafstörungen: Kapitel "Insomnie bei Erwachsenen" (AWMF-Registernummer 063-003), Update 2016. Somnologie 2017;21(1):2-44.

https://doi.org/10.1007/s11818-016-0097-x

5. Choueiry N, Salamoun T, Jabbour H, El Osta N, Hajj A, Rabbaa Khabbaz L. Insomnia and relationship with anxiety in university students: a cross-sectional designed study. PLoS ONE 2016;11(2):e0149643.

https://doi.org/10.1371/journal.pone.0149643

6. Belingheri M, Pellegrini A, Facchetti R, De Vito G, Cesana G, Riva MA. Self-reported prevalence of sleep disorders among medical and nursing students. Occup Med 2020;70(2):127-30. https://doi.org/10.1093/occmed/kqaa011

7. Alsaggaf MA, Wali SO, Merdad RA, Merdad LA. Sleep quantity, quality, and insomnia symptoms of medical students during clinical years. Saudi Med J 2016;37(2):173-82.

https://doi.org/10.15537/smj.2016.2.14288

8. Alqudah M, Balousha SAM, Al-Shboul O, Al-Dwairi A, Alfaqih MA, Alzoubi KH. Insomnia among medical and paramedical students in Jordan: impact on academic performance. BioMed Res Int 2019.

https://doi.org/10.1155/2019/7136906

9. Taylor DJ, Bramoweth AD, Grieser EA, Tatum JI, Roane BM. Epidemiology of insomnia in college students: relationship with mental health, quality of life, and substance use difficulties. Behav Ther 2013;44(3):339-48.

https://doi.org/10.1016/j.beth.2012.12.001

10. Williams AB, Dzierzewski JM, Griffin SC, Lind MJ, Dick D, Rybarczyk BD. Insomnia disorder and behaviorally induced insufficient sleep syndrome: prevalence and relationship to depression in college students. Behav Sleep Med 2020;18(2):275-86. https://doi.org/10.1080/15402002.2019.1578772

11. Garuolienė K. Psichotropinių vaistų suvartojimas Lietuvoje ir Europoje. Psichiatrijos naujienos, 2016; 1(1): 6-7.

\section{INSOMNIA SYMPTOMS EXPERIENCED BY VILNIUS UNIVERSITY FACULTY OF MEDICINE STUDENTS \\ B. Balčiūnaitè, V. Būgaitè, M. Karnickas}

Keywords: insomnia, benzodiazepines, $\mathrm{Z}$ drugs.

Summary

Background. Biomedical students often experience sleep disorders. The aim of this study was to determine the prevalence of insomnia symptoms among students in the Faculty of Medicine of Vilnius University and to evaluate the severity of those symptoms according to the Insomnia Severity Index (ISI), as well as to determine which methods biomedical students use to alleviate sleep disorders.

Materials and methods. Between the months of December 2020 and February 2021, 416 students of biomedicine at the Faculty of Medicine of Vilnius University partook in an online questionnaire composed of 32 multiple-choice questions. The data received was processed using the " Microsoft Excel" program and was found to be statistically significant when $\mathrm{p}<0.05$.

Results. Students from all Faculty of Medicine programs were questioned (medicine $-44.5 \%$, pharmacy $-12.3 \%$, kinesiotherapy - $12.3 \%$, odontology $-8.9 \%$, public health $-8.9 \%$, ergotherapy $7.2 \%$, nursing - $5 \%$, "other" - $1 \%$ ). Out of 416 respondents, 352 $(84.6 \%)$ were women and $64(15.4 \%)$ were men. Statistically significant insomnia symptoms according to the Insomnia Severity Index were experienced by 165 students out of 416 (39.7\%). Clinical insomnia symptoms of moderate severity were experienced by 119 out of 416 students (29\%). Severe clinical insomnia symptoms were experienced by 46 out of 416 students (11\%). Only 50 $(12 \%)$ out of 416 biomedical students were aware that the maximum prescribed length of acute insomnia treatment with benzodiazepines was one month. Out of 227 students who experienced symptoms of insomnia, $65(28.6 \%)$ imbibed alcohol as a method of facilitating the process of falling asleep. Out of 227 students who experienced symptoms of insomnia, 152 (67\%) stated their use of herbal preparations, $87(38.3 \%)$ - melatonin compounds, $54(23.8 \%)$ - benzodiazepines, 28 (12.3\%) - antidepressants, 20 (8.8\%) - Z drugs, 8 (3.5\%) - quetiapine, and 56 (24.7\%) stated no use of any of the mentioned medications. Of the 54 students who had used benzodiazepines to treat symptoms of insomnia, 18 $(33.3 \%)$ experienced at least 1 side effect and $4(7.4 \%)$ matched the diagnostic criteria for addiction. Out of the 20 students who had used $\mathrm{Z}$ drugs to treat symptoms of insomnia, 11 (55\%) experienced at least one side effect and 3 (15\%) matched the diagnostic criteria for addiction.

Conclusions. Clinically significant insomnia symptoms according to ISI were experienced by 165 (39.7\%) out of 416 students. Female students got statistically significantly higher ISI scores in comparison to male students $(\mathrm{p}=0.0034)$. Non-medical students got statistically significantly higher ISI scores in comparison to medical students ( $\mathrm{p}=0.0001)$. The highest prevalence of insomnia symptoms was determined to be among kinesiotherapy students (55\%) while the lowest - among medical students (31\%).

Correspondence to: vaiva.bugaite@gmail.com

Gauta 2021-03-11 